\title{
Spatial fields' dispersion as a farmer strategy to reduce agro-climatic risk at the household level in pearl millet-based systems in the Sahel: A modeling perspective
}

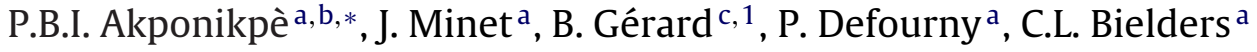 \\ a Université catholique de Louvain (UCL), Earth and Life Institute, Croix du Sud 2, Boite 2, B-1348 Louvain-la-Neuve, Belgium \\ ${ }^{\mathrm{b}}$ Université de Parakou (UP), Faculté d'Agronomie (FA), Environmental Soil Physics and Hydraulics Unit (PSHE), BP 123, Parakou, Benin

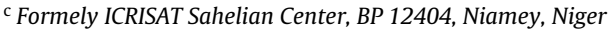

\section{A R T I C L E I N F O}

\section{Article history:}

Received 1 October 2009

Received in revised form 7 October 2010

Accepted 21 October 2010

\section{Keywords:}

Rainfall

Variability

Agro-climatic risk

Field dispersion

Millet

GIS

Soil fertility

\begin{abstract}
A B S T R A C T
The rainfall pattern in the Sahel is very erratic with a high spatial variability. We tested the often reported hypothesis that the dispersion of farmers' fields around the village territory helps mitigate agro-climatic risk by increasing yield stability from year to year. We also wished to evaluate whether this strategy had an effect on the yield disparity among households in a village. Based on a network of approximately 60 rain gauges spread over $500 \mathrm{~km}^{2}$ in the Fakara region (Southwest Niger), daily rainfall was interpolated at $300 \mathrm{~m} \times 300 \mathrm{~m}$ resolution over a 12 -year period. This data was used to compute, by means of the APSIM crop simulation model, millet biomass and grain yields at the pixel scale. Simulated yields were combined with the land tenure map of the Banizoumbou village in a GIS to assess millet yield at field and household level. Agro-climatic risk analysis was performed using linear regression between a spatial dispersion index of household fields and the inter-annual (instability) and inter-household (disparity) millet yield variability of 107 households in the village territory. We find that the spatial variability of annual rainfall induces an even higher spatial variability of millet production at pixel, field and household levels. The dispersion of farm fields reduces moderately but significantly the disparity of millet yield between households each year and increases the inter-annual yield stability of a given household. The less the household fields are scattered, the more the presence of a fertility gradient around the village enhances the inter-annual stability but also the disparity between households. Our results provide evidence that field dispersion is an effective strategy to mitigate agro-climatic risk, as claimed by farmers in the Sahelian Niger. Although the results should be confirmed by further research on longer term rainfall spatial data, it is clearly advisable that any land reforms in the area take into account the benefits of field dispersion to mitigate climatic risk.
\end{abstract}

(C) 2010 Elsevier B.V. All rights reserved.

\section{Introduction}

Sahelian rainfed cropping systems are characterized by a high climatic risk due to limited rainfall and frequent intra-seasonal droughts, both factors being highly variable in space over short distances. Together with the low inherent soil fertility, these are the main biophysical factors limiting the development of Sahelian agriculture, on which the major part of the population depends. Pearl millet [Pennisetum glaucum (L.) R.Br.], the main staple crop, is grown during the short rainy season from May-June to September, dur-

\footnotetext{
* Corresponding author at: Université de Parakou (UP), Faculté d'Agronomie (FA), Environmental Soil Physics and Hydraulics Unit (PSHE), BP 123, Parakou, Benin.

E-mail address: akponikpe@yahoo.com (P.B.I. Akponikpè).

1 Now at: International Livestock Research Institute (ILRI), P.O. Box 5689, Addis Ababa, Ethiopia.
}

ing which the temporal rainfall pattern and the date of onset of the rainy season largely determine crop yield (Sivakumar, 1992). For example in Niamey, the length of the growing season is positively correlated with the earliness of the onset of rains, the date of onset being much more variable from one year to another than the date of ending of the raining season (Sivakumar, 1990). Occurrence of dry spells is also critical, especially when they strike at crop growth stages such as emergence or grain filling.

Temporal rainfall variability has been studied in Niger at different time scales (year, month, day and hour). The inter-annual coefficient of variation (CV) of rainfall for different locations in Southwest (SW)-Niger was found to vary between 17\% and 32\% (Sivakumar, 1989) for a mean long term annual rainfall ranging between 300 and $600 \mathrm{~mm}$ (Le Barbe and Lebel, 1997). More essential to agriculture is the daily rainfall variability expressed as the amount of rain per rainy day and the interval between rainy days. At the ICRISAT Sahelian Centre (ISC, Sadoré, Niger), the average 
amount of rain per day increases from $9.7 \mathrm{~mm}$ to $14.4 \mathrm{~mm}$ during the course of the rainy season. However, the standard deviation (SD) at the same time increases from $7.6 \mathrm{~mm}$ to $11.1 \mathrm{~mm}$. The mean interval between successive rainfall events decreases during the course of the rainy season from 6 to 2 days (Graef, 2000).

Spatially, rainfall can vary considerably even over distances of a few kilometers depending on the time scale considered. The regional rainfall data for SW-Niger shows a higher variability in a latitudinal $(\mathrm{N}-\mathrm{S})$ than in a longitudinal $(\mathrm{W}-\mathrm{E})$ direction. This is associated with a systematic north-south long term mean annual rainfall gradient of approximately $1 \mathrm{~mm}$ rainfall $\mathrm{km}^{-1}$. Annual differences of 200-300 mm may occur in any direction within a radius of only $100 \mathrm{~km}$ (Graef, 2000). A maximum annual rainfall gradient of $42 \mathrm{~mm} \mathrm{~km}^{-1}$ and $64 \mathrm{~mm} \mathrm{~km}^{-1}$ was found across the 500 ha ISC research station in 1995 and 1996, respectively. Differences in daily rainfall may exceed $20-40 \mathrm{~mm}$ over a distance of only 2-3.2 km distance (Flitcroft et al., 1989; Graef, 2000), which may have a major impact on crop growth.

This spatio-temporal variability of rainfall may induce an important space-time variability of millet growth and yield (Graef and Haigis, 2001). The spatial variability of millet yield has been reported at the plant, field and regional level (e.g., Brouwer et al., 1993; Voortman et al., 2004). The micro-variability of yield was mainly attributed to soil physical and chemical characteristics, and to shrub distribution (e.g., Gérard and Buerkert, 1999; Voortman et al., 2004). However, the field scale and regional scale yield variability are strongly governed by the spatial and temporal distribution of rainfall, and for similar soils and fertility management practices, it is not rare to have drastically different yields between fields separated by a few kilometres only (Graef and Haigis, 2001).

Graef and Haigis (2001) conducted socio-economic surveys in two villages and reported that smallholder farmers have adopted a range of management strategies to reduce agro-climatic risk and to try to secure at least a minimum yield each year. One such strategy is the dispersion of fields cultivated by a single household throughout the village territory. Indeed, farmers prefer to have several small dispersed fields rather than one large field. Other spatial factors, such as the distance from the field to the village, were also mentioned as playing a crucial role in the reduction of the climatic risk because of the water/fertility interaction. Indeed, on average, fields located close to the village are known to have higher fertility than more distant fields because they benefit from higher levels of organic amendment inputs (Hiernaux and Ayantunde, 2004). Under good rainfall conditions, high fertility fields are expected to lead to better yields than low fertility fields, whereas these same high fertility fields may suffer more severely from drought than low fertility fields under poor rainfall conditions depending on the time of occurrence of the drought. According to Graef (2000), most farmer fields are dispersed within a distance of $1-5 \mathrm{~km}$. Although regarded as a common wisdom, the actual contribution of the field dispersal strategy to the mitigation of climatic risk has never been evaluated. This strategy is particularly difficult to evaluate under field conditions because of the multiplicity of spatially highly variable factors affecting yields: soil chemical fertility, soil hydrodynamic properties and crusting (Hoogmoed and Stroosnijder, 1984; Valentin, 1991; Valentin and D'herbes, 1999; Hunt, 2000), rainfall distribution, pests and diseases, field history, site-specific management practices, irregular sowing densities and genetic variability of local millet cultivars.

Crop simulation models are appropriate tools for assessing the climate and fertility-related production variability associated with particular management strategies in agricultural systems. Thornton et al. (1997) developed a prototype GIS-based, real-time yield forecasting system for Burkina Faso that uses the CERES-Millet model and satellite-derived precipitation estimates combined with historical weather data series. The integration in a GIS of spatially distributed weather data and soil fertility information with crop simulation models appears as the most suitable approach for evaluating the relevance of farmers' climatic risk management strategies, and to quantify the contribution of field dispersion in mitigating that risk.

The objective of this work is therefore to evaluate the impact of spatial dispersion of farmer's fields on two agro-climatic risk indicators through a spatial analysis which integrates GIS-based land tenure information, soil fertility strata and spatial rainfall information with the APSIM millet growth simulation model. This agro-climatic risk is assessed at the household level by considering inter-annual yield variability. It is also assessed at the village scale, by investigating yield disparity among households. More specifically, we seek to address the following questions in the context of Sahelian subsistence agriculture: (1) as a result of rainfall spatial variability, do multiple scattered fields ensure greater inter-annual millet yield stability than a single field for a given household; (2) does household field dispersion affect the disparity among households of the village in terms of millet yield; and (3) does the presence of a soil fertility gradient around the village affect the results?

\section{Materials and methods}

\subsection{Study area}

The study focuses on a $15 \mathrm{~km} \times 15 \mathrm{~km}$ area centred on the village of Banizoumbou $\left(13^{\circ} 32^{\prime} \mathrm{N}, 2^{\circ} 40^{\prime} \mathrm{E}\right)$, located in the canton of Fakara $\left(500 \mathrm{~km}^{2}\right) 75 \mathrm{~km}$ east of Niamey, Niger (Fig. 1).

The climate of the Fakara region is a typical inland semi-arid tropical climate. Being close to Niamey and approximately at the same latitude, the long term climatic characteristics can be considered similar to those of Niamey, with an average annual rainfall of $560 \mathrm{~mm}$ for the period 1905-1989. Rainfall occurs in summer when days are long, ambient temperatures are elevated, and potential evapotranspiration is high. Rainfall distribution is strictly monomodal, centred in August, with rainy seasons lasting 3-4

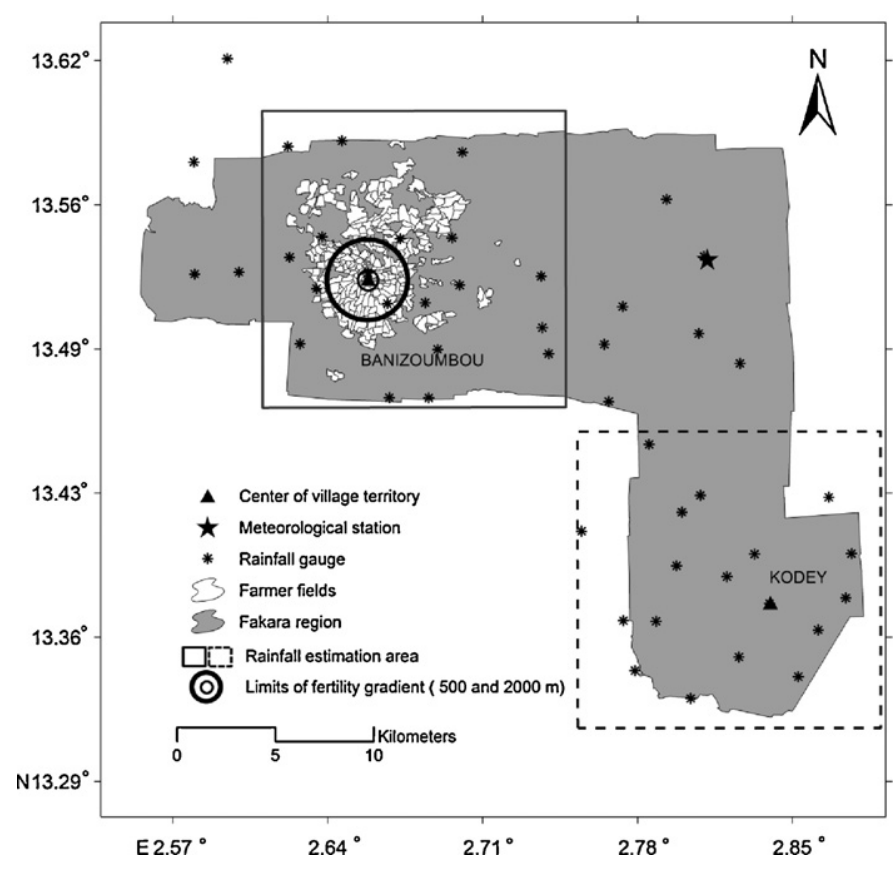

Fig. 1. The Fakara study site, Banizoumbou land tenure and ICRISAT rain gauge network. Banizoumbou is located at the centre of the circles defining the limits of fertility gradients. 
months. The average date ( \pm standard deviation) of onset of the rainy season is 12 June ( \pm 18 days) and the average date of ending of rains is 27 September ( \pm 12 days) (Sivakumar, 1988).

Soils differ across the landscape but all tend to have low organic carbon content $(<0.3 \%)$ and a weakly developed structure. Soils used for millet cropping are mainly sandy ( $>85 \%$ sand) and belong to the arenic Gleysol, gleyic Arenosol, leptic Lixisol, arenic Lixisol, and arenic Cambisol types (Hiernaux and Ayantunde, 2004). Topsoils are acidic and poor in total nitrogen and available phosphorus with generally very low cation exchange capacity (1-2 cmol kg-1).

The cropping system is largely subsistence-oriented, based on millet sometimes associated with a range of secondary crops, either dual-purpose legumes (cowpea) or cash crops (sesame, sorrel). Because of the sandy texture, zero tillage is practiced and the labour bottleneck is the two seasonal weedings. No mechanical power is available and weeding is done by hand using a "hilaire". Average land cropped or left fallow per household is 13.7 ha, reflecting the low population density (La Rovere et al., 2004). The land used by a household is on average divided among 2.7 non-contiguous blocks. These blocks may in practice be subdivided into management units (fallow, different crop associations, different history, etc.).

\subsection{GIS household-level land tenure data}

Household-level land tenure (household field ownership) refers hereafter to the set of geo-referenced, individual fields cropped by a given household. The land tenure map of the Banizoumbou territory was established by a research team of the International Livestock Research Institute (ILRI) by combining aerial and satellite imagery and an exhaustive socio-economic survey of the households in the area between 1994 and 1996 (Fig. 1) (Hiernaux and Ayantunde, 2004). All fields cultivated by 107 households are included in this map. We considered all fields in the land tenure map as being cropped every year with millet although a few of them may in reality be left fallow in part or in total. The vector information of the observed land tenure of Banizoumbou was converted into raster with a pixel resolution of $100 \mathrm{~m}$. The pixel size was imposed by the smallest field size.

\subsection{Spatial rainfall estimation}

Precipitation data from two rainfall monitoring networks were used. The first network, maintained by the Institut de Recherche pour le Développement (IRD, Niamey), comprised 66 rainfall gauges regularly spaced on a $1700 \mathrm{~m} \times 900 \mathrm{~m}$ grid covering an area of $10 \mathrm{~km} \times 10 \mathrm{~km}$. Daily rainfall was monitored during the 2006 rainy season. The second network, maintained by ICRISAT, comprised between 50 and 70 rainfall gauges (depending on the year) distributed randomly across the Fakara region (Fig. 1). Rainfall was recorded daily from 2000 to 2005 during the rainy seasons. Rainfall gauges were spaced between 1 and $5 \mathrm{~km}$ from each other. The $15 \mathrm{~km} \times 15 \mathrm{~km}$ Banizoumbou village territory was covered by 20 rainfall gauges.

Data from the two rain gauge networks were first checked for consistency and abnormal values. Because the density of the ICRISAT rain gauge network proved insufficient to properly evaluate the spatial dependence (semi-variogram) of daily rainfall, the IRD network was used for this purpose. Twenty-three rainfall events from the IRD network were selected and used to derive a mean variogram model of the daily rainfall spatial variability. The variograms were computed for each rainfall event and then averaged. A nested gaussian-spherical model was fitted to the mean variogram using the BMELIB2.0b Matlab ${ }^{\circledR}$ geostatistical library (Christakos et al., 2002). The derived variogram model from the IRD network was used with the measured data of the ICRISAT network to estimate daily rainfall for all the 2500 pixels $(300 \mathrm{~m} \times 300 \mathrm{~m}$ in size) of the $15 \mathrm{~km} \times 15 \mathrm{~km}$ Banizoumbou area over a 6-year period (2000-2005) using the Cholesky conditional interpolation function of BMELIB2.0b. Estimated daily rainfall values less than zero were considered as null. In order to double the temporal range of rainfall conditions beyond the six years of observed data at Banizoumbou, the spatial rainfall data from the nearby village of Kodey $\left(13^{\circ} 22^{\prime} \mathrm{N}, 2^{\circ} 51^{\prime} \mathrm{E}, 26 \mathrm{~km}\right.$ from Banizoumbou, Fig. 1), also covering a $15 \mathrm{~km} \times 15 \mathrm{~km}$ area, were superimposed on the Banizoumbou land map. This area was covered by a network of 17 rainfall gauges and observed values were interpolated using the same procedure as for Banizoumbou. Rainfall data from Banizoumbou and Kodey were considered spatially independent, given that the range of the daily rainfall variogram is of the order of a few kilometres whereas the two villages are $26 \mathrm{~km}$ apart.

\subsection{Model evaluation and simulations}

\subsubsection{Spatial millet biomass and grain yield simulations}

Five modules - a specific millet crop module (APSIM-millet 3.6), a soil water module (Soilwat2), the soil nitrogen (Soiln2), the residue (Residue2) and the manure (Manure) modules - were linked within the APSIM crop simulation model (Agricultural Production Systems Simulator; Keating et al., 2003) to simulate the cases described in this paper. Input data required by the APSIM model are related to the soil chemical and physical properties, crop genetic characteristics, crop management (sowing, soil amendments, etc.) and climate data. For the simulations in this work, the crop genetic characteristics used were those of the most commonly cropped millet landrace (Hainikirey) in the region. APSIM was parameterized for this cultivar based on detailed phenological data collected at ICRISAT Sadoré in 2005 (Akponikpè, 2008). Sowing and resowing of millet, a common practice in case of crop failure, were parameterized to mimic common farmer practices in the area. During each simulation year, millet sowing was allowed when a total rainfall over $15 \mathrm{~mm}$ occurred over three consecutive days between May 01 and June 30 each year. Only $10 \mathrm{~mm}$ was required to initiate sowing between the $1 \mathrm{st}$ and 30th of July if no sowing was possible previously or if the crop sown previously failed due to severe drought. Crop permanent wilting, possibly leading to resowing, was reached when the simulated crop water deficit factor dropped under 0.5 for 15 consecutive days. No sowing or resowing was allowed after July 30 because after this date the remaining growing season would inevitably be too short. Plant density was set to 15,000 plants ha $^{-1}$, which is comparable to the densities found in farmer fields in the area (Payne, 2000).

Initial soil chemical and physical parameterization was based on literature and published results of previous crop model validation works with CERES (Fechter, 1993) and APSIM (Akponikpè, 2008). Initial soil chemical properties were reset at each simulation year. As the purpose of this study was to assess the contribution of rainfall variability to yield variability, no random sources of variability in soil properties were considered. Furthermore, the parameterization of this random variability would not have been possible given the available data. However, a non-random source of soilrelated yield variability was integrated in the modeling, i.e., the fertility gradient around the village. Two scenarios were tested: (1) no fertility gradient ( $-\mathrm{FG}$ ); in this case, $300 \mathrm{~kg} \mathrm{ha}^{-1}$ millet residue was applied to every pixel, which is representative of the amount usually found in most farmer fields before planting (Baidu-Forson, 1995), (2) fertility gradient (+FG) around the village: $300 \mathrm{~kg} \mathrm{ha}^{-1}$ crop residue plus 3000,300 or $0 \mathrm{~kg} \mathrm{ha}^{-1}$ manure applied when the simulated pixel is located $0-500 \mathrm{~m}, 500-2000 \mathrm{~m}$ or over $2000 \mathrm{~m}$, respectively, from the village centre (Fig. 1). Levels of manure application were chosen to mimic the existing soil fertility gradient around villages in the area. Manure nutrient content was $1.0 \% \mathrm{~N}$ 


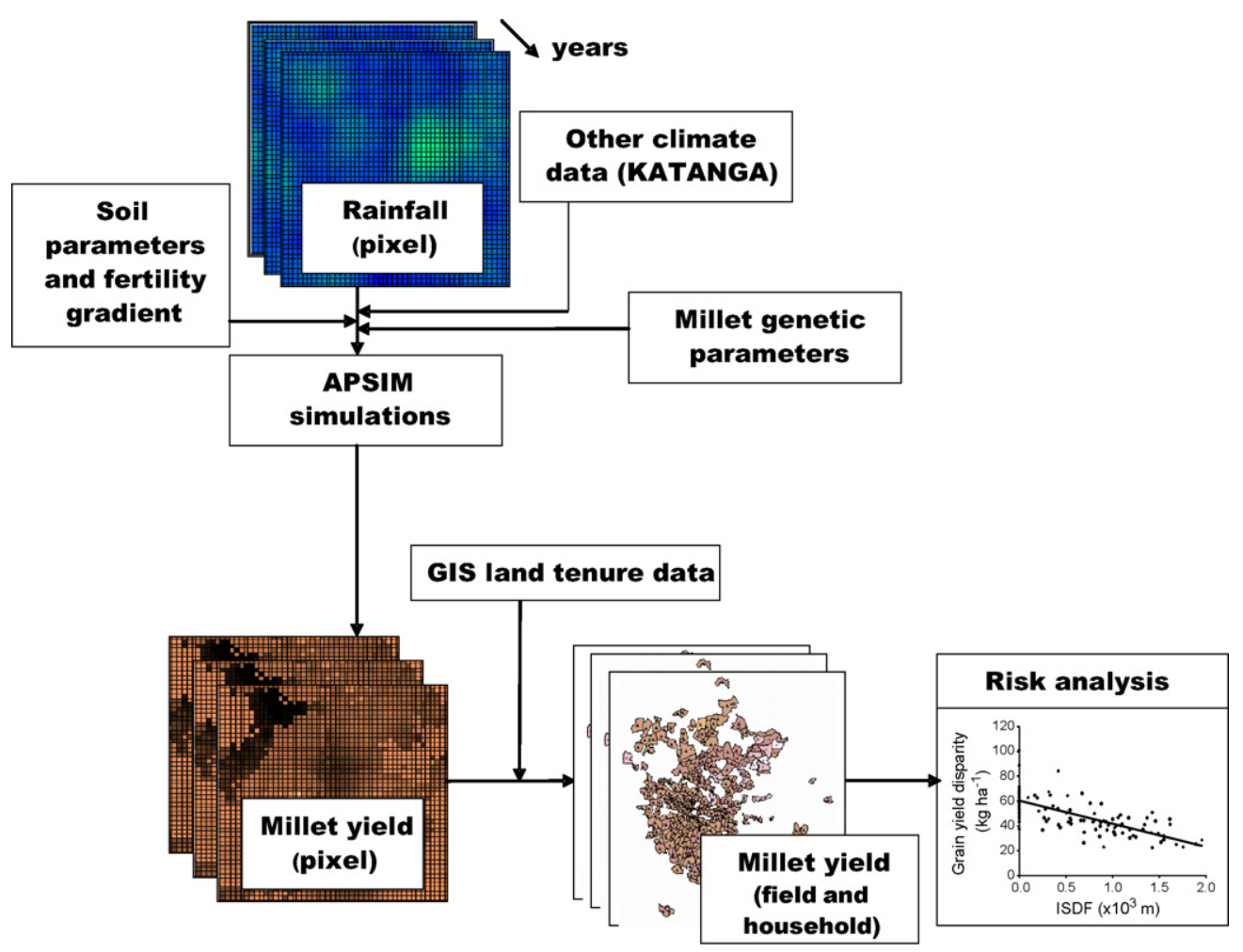

Fig. 2. Diagram of the combined GIS and modeling approach used to evaluate the relation between household fields' spatial dispersion and agro-climatic risks.

and $0.2 \% \mathrm{P}$ (mean). Average millet crop residue nutrient content was $0.74 \% \mathrm{~N}$ and $0.05 \% \mathrm{P}$.

Climate data (minimum and maximum temperatures, solar radiation) were recorded daily over the 6 years by means of a Campbell CR10 automatic weather station located at the Katanga village, approximately $10 \mathrm{~km}$ away from Banizoumbou (Fig. 1). These data were used to calculate the Priestley-Taylor potential evaporation and were considered spatially homogeneous. The spatially homogeneous crop genetic properties, temperature and solar radiation data were combined with the spatially variable rainfall data $(2 \times 6$ years) and the fertility gradient in the APSIM model to simulate millet biomass and grain yield at each of the 2500 pixels $(300 \mathrm{~m} \times 300 \mathrm{~m}$ size). Each $300 \mathrm{~m} \times 300 \mathrm{~m}$ climate pixel of the simulated area was then subdivided into nine $100 \mathrm{~m} \times 100 \mathrm{~m}$ land tenure pixels with equal yield, as simulated by APSIM. The biomass and grain yield of a given field was computed as the average value of all $100 \mathrm{~m} \times 100 \mathrm{~m}$ pixels falling within it. An overview of the simulation approach and its integration with spatial data in a GIS is presented in Fig. 2.

\subsubsection{APSIM model evaluation in the Sahel}

In order to ensure that the simulated millet grain and total aboveground biomass yields match the agronomic reality in the Sahel, the APSIM model was tested against data from a rainfed randomized complete block experiment carried out at ICRISAT, Sadoré under soil and climatic conditions that are similar to those of the Fakara. The experiment was run during the 1994 and 1995 cropping seasons, which presented contrasting rainfall conditions. The experiment combined, at three levels each, the application of cattle manure (300, 900 and $\left.2700 \mathrm{~kg} \mathrm{ha}^{-1}\right)$, millet residue $\left(300,900\right.$ and $\left.2700 \mathrm{~kg} \mathrm{ha}^{-1}\right)$ and mineral fertilizer (unfertilized control, $15 \mathrm{~kg} \mathrm{~N} \mathrm{ha}^{-1}+4.4 \mathrm{~kg} \mathrm{P} \mathrm{ha}^{-1}$ and $45 \mathrm{~kg} \mathrm{Nha}^{-1}+13.1 \mathrm{~kg} \mathrm{Pha}^{-1}$ ). These rates encompass commonly found manure and millet stover rates observed in farmer fields. Details of this APSIM testing to simulate the millet response to water and nutrient management can be found in Akponikpè et al. (2006, 2010).

\subsubsection{Ground checking in farmer fields}

As part of activities unrelated to the present paper, millet yields were monitored in the fields of two farmers during the 2004 and 2005 rainy seasons in the Banizoubou territory. These fields were managed by the farmers themselves without any external intervention. Small plots $\left(100-400 \mathrm{~m}^{2}\right)$ were delineated inside $2-3$ fields per farmer and total grain and above ground biomass were measured at harvest.

\subsection{Household field dispersion and agro-climatic risk indicators}

\subsubsection{Household field dispersion index}

We used the index of the spatial dispersion of the fields (ISDF; [m]) owned by a given household $k$, defined as the pair-wise average distance between them, weighted by the product of field areas (Marinho, 2008):

$\operatorname{ISDF}_{k}=\frac{\sum_{i=1}^{n} \sum_{j=i+1}^{n} d_{i, j}\left(s_{i} \cdot s_{j}\right)}{\left(\sum_{i=1}^{n} s_{i}\right)^{2}}$

where $s_{i}$ and $s_{j}$ are respectively the area of field $i$ and $j$, and $d_{i, j}$ is the Euclidian distance between the field centroids. ISDF equals zero for a household owning a single field. ISDF was proven to be more consistent than the often used Convex Hull index (Bishop, 2007) as it is sensitive to distance between fields and independent of both the number of farm fields and the total farm area owned by a given household (Marinho, 2008).

\subsubsection{Agro-climatic risk indicators}

Two agronomic risk indices were computed:

1. The inter-annual, standard deviation of millet grain [INST(GY)] or biomass [INST(BY)] yield, calculated for each household sepa- 
rately. Let $Y_{i j k}$ be the grain yield $\left(\mathrm{kg} \mathrm{ha}^{-1}\right)$ of field $i$ of household $j$ during year $k, s_{i}$ the area (ha) of field $i$ and $m$ the number of fields cultivated by household $j$, then the weighted average grain yield in household $j$ during year $k$ is given by:

$Y_{j k}=\frac{\sum_{i=1}^{m} s_{i} Y_{i j k}}{S_{J}}$

where

$S_{j}=\sum_{i=1}^{m} s_{i}$

is the total area cultivated by household $j$. The average grain yield of household $j$ over $n$ cropping years is given by:

$Y_{j}=\frac{1}{n} \sum_{k=1}^{n} Y_{j k}$

The grain yield INST(GY) index [ $\left.\mathrm{kg} \mathrm{ha}^{-1}\right]$ for household $j$ is then given by:

$\operatorname{INST}(\mathrm{GY})_{j}=\sqrt{\frac{1}{n-1} \sum_{k=1}^{n}\left(Y_{j k}-Y_{j}\right)^{2}}$

INST(BY) [ $\left.\mathrm{kg} \mathrm{ha}^{-1}\right]$ was calculated in a similar way, replacing millet grain yield by total aboveground millet biomass $\left(\mathrm{kg} \mathrm{ha}^{-1}\right)$. The lower the value of INST(GY) or INST(BY), the more stable grain and biomass yield are over years for a given household. INST(GY) or INST(BY) are thus indicators of temporal yield stability for one household. All other conditions being equal, a higher temporal variability in yield would be indicative of a higher risk of obtaining very low yields in some years.

2. The inter-annual, standard deviation over years of grain [DISP(GY)] or biomass [DISP(BY)] yield relative to the average yield across the village territory. The average yield across the village territory in year $k$ is given by:

$Y_{k}=\frac{\sum_{j=1}^{h} S_{j} Y_{j k}}{\sum_{j=1}^{h} S_{j}}$

where $h$ is the total number of households. The DISP(GY) $\left[\mathrm{kg} \mathrm{ha}^{-1}\right]$ index for household $j$ is then given by:

$\operatorname{DISP}(\mathrm{GY})_{j}=\sqrt{\frac{1}{n-1} \sum_{k=1}^{n}\left(Y_{j k}-Y_{k}\right)^{2}}$

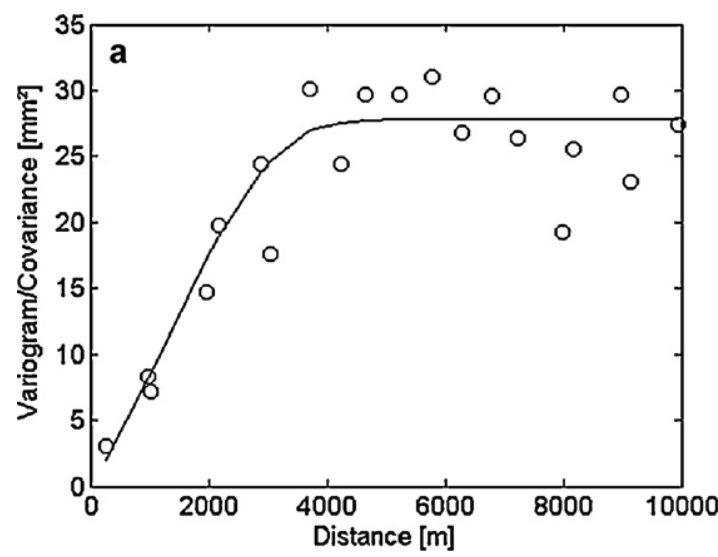

The biomass yield DISP(BY) $\left[\mathrm{kg} \mathrm{ha}^{-1}\right]$ index is calculated in a similar way, replacing millet grain yield by total aboveground millet biomass. The lower the value of DISP(GY) or DISP(BY), the closer the grain and biomass yield of a given household are to the average village scale yield each year. DISP(GY) or DISP(BY) are thus indicators of yield disparity between households in the territory.

Results were analyzed in terms of the cumulative probability density distribution of the two agro-climatic risk indices with or without consideration of a fertility gradient. Linear regression analysis between the index of spatial dispersion of the fields (ISDF) and the agro-climatic risk indices (INST and DISP) was also performed.

\section{Results}

\subsection{Spatial rainfall, sowing events and millet yields}

\subsubsection{Annual rainfall spatial distribution}

The characteristics of the variogram fitted to the IRD rain gauge data can be summarized as follows: $12 \mathrm{~mm}^{2}$ sill, a range of $4 \mathrm{~km}$ and no nugget effect (Fig. 3a). A leave-one-out cross validation of the estimated rainfall vs. predicted rainfall was performed for the 12 years for each event (Fig. 3b). The estimation of rainfall at measured locations was rather fair $\left(r^{2}=0.39\right)$. Several explanations can be provided for this. First, it has been assumed that the spatial rainfall pattern of all events can be modeled by the same mean variogram model derived from samples of unknown large population. This assumption could be refined by considering different models for different types of rainfall events, but a detailed classification of the rainfall events is beyond the scope of this study. Second, the raingauge network used for deriving the variogram model is different from the network to which it is applied. Although located at the same site, this may have an impact on the actual variogram. Third, it was also assumed that the variogram derived from the 2006 IRD raingauge network is applicable to the 2000-2005 rainfall series covered by the ICRISAT network rainfall measurements.

The resulting rainfall maps for the Banizoumbou rainfall dataset are given in Fig. 4. The household-average annual rainfall ranged from 395 to $505 \mathrm{~mm}$ across the 6 years of observations over the 2 sites (Table 1). Although the CV between rainfall of all households in the territory in a given year is rather low (4-10\%; Table 1 ), important variability of annual cumulative rainfall between households was found, the difference between wettest and driest households ranging between 100 and $158 \mathrm{~mm}$ for Banizoumbou and 109 and $212 \mathrm{~mm}$ for Kodey depending on the year.

However, the spatial variability of rainfall at pixel level for a given year and site was much larger than the household averaged

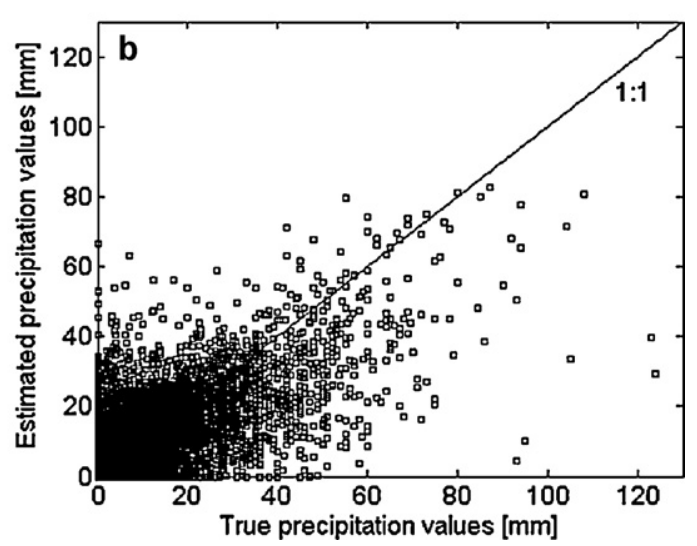

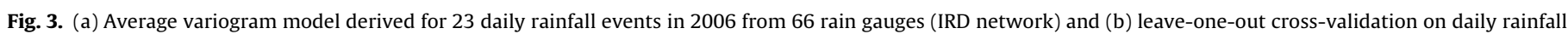
over 12 years for approximately 60 rain gauges (ICRISAT network), in Banizoumbou, Niger. 

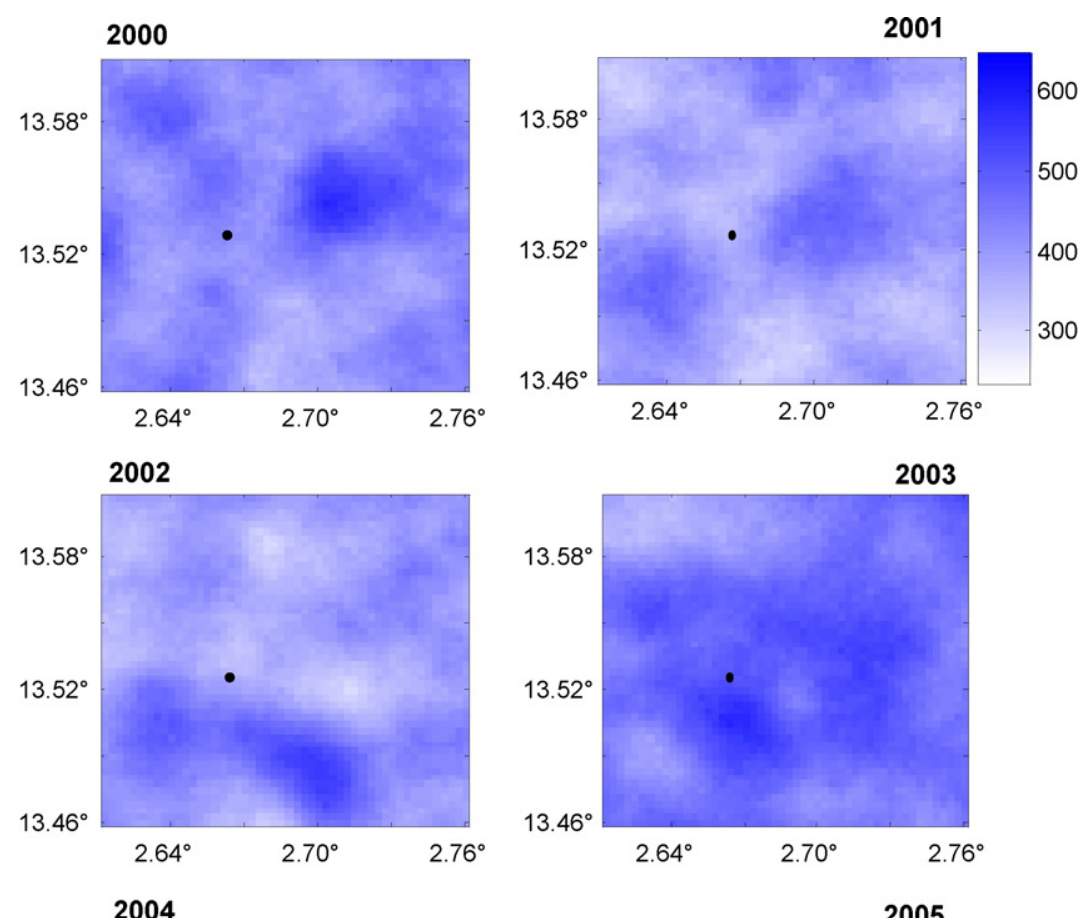

2004

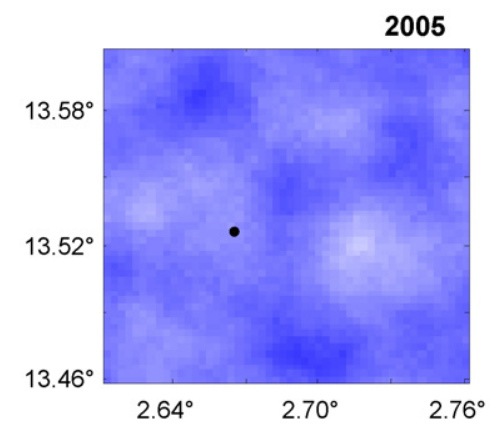

Fig. 4. Spatially estimated rainfall [mm] at pixel level ( $300 \mathrm{~m} \times 300 \mathrm{~m})$ from 2000 to 2005 at Banizoumbou, Niger. The black dot is the centre of the Banizoumbou village.

variability. Indeed, the difference between the wettest and driest pixels $(300 \mathrm{~m} \times 300 \mathrm{~m})$ ranged between 197 and $262 \mathrm{~mm}$ for Banizoumbou (Fig. 4) and 187 and $265 \mathrm{~mm}$ for Kodey (not shown) depending on the year. In addition, despite the limited range in the spatially averaged yearly rainfall values, the spatial rainfall pattern varied greatly across years (Fig. 4). At a daily scale, the spatial heterogeneity was even larger.

\subsubsection{APSIM model performance}

Compared to measurements performed during the on-station experiment, the APSIM model suitably predicted plant available water (PAW) (Akponikpè et al., 2010). Depending on the date, the PAW root mean square error (RMSE) represented between $0.8 \%$ and $1.8 \%$ of the total PAW over the entire rooting depth $(0-1.50 \mathrm{~m})$. For biomass and grain yield (Fig. 5), the model performance was

Table 1

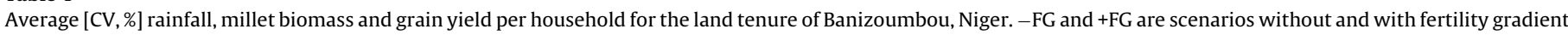
around the village, respectively.

\begin{tabular}{|c|c|c|c|c|c|c|}
\hline & & \multirow[t]{2}{*}{ Rainfall (mm) } & \multicolumn{2}{|c|}{ Biomass $\left(\mathrm{kg} \mathrm{ha}^{-1}\right)$} & \multicolumn{2}{|c|}{ Grain $\left(\mathrm{kg} \mathrm{ha}^{-1}\right)$} \\
\hline & & & $-\mathrm{FG}$ & $+\mathrm{FG}$ & $-\mathrm{FG}$ & $+\mathrm{FG}$ \\
\hline \multirow[t]{6}{*}{ Baniz. $^{a}$} & 2000 & $431[7]$ & $1777[25]$ & $1886[28]$ & $338[20]$ & $355[22]$ \\
\hline & 2001 & 395 [7] & $2594[11]$ & $2710[15]$ & $445[10]$ & $461[12]$ \\
\hline & 2002 & 398 [8] & $3031[6]$ & 3082 [7] & $542[5]$ & $553[6]$ \\
\hline & 2003 & $505[4]$ & $1609[18]$ & 1763 [19] & 298 [13] & 328 [15] \\
\hline & 2004 & 395 [7] & 2183 [19] & $2273[22]$ & $407[18]$ & $421[20]$ \\
\hline & 2005 & $445[5]$ & $2665[14]$ & $2781[17]$ & $471[13]$ & $490[14]$ \\
\hline \multirow[t]{6}{*}{ Baniz. $^{b}$} & 2000 & 469 [7] & $1816[26]$ & 1940 [29] & $334[21]$ & $352[22]$ \\
\hline & 2001 & 395 [7] & 2499 [13] & 2619 [17] & $439[10]$ & $455[12]$ \\
\hline & 2002 & $500[4]$ & $2963[8]$ & $3063[11]$ & $521[4]$ & $534[6]$ \\
\hline & 2003 & $396[9]$ & $2378[4]$ & $2509[11]$ & $419[4]$ & $441[10]$ \\
\hline & 2004 & $474[6]$ & $2917[5]$ & 3005 [8] & $529[4]$ & $543[6]$ \\
\hline & 2005 & $455[10]$ & $2755[12]$ & $2862[15]$ & $478[11]$ & 494 [13] \\
\hline
\end{tabular}

\footnotetext{
a Land tenure and rainfall data for the Banizoumbou territory.

b Land tenure data from Banizoumbou but rainfall data from another but closeby territory (Kodey).
} 


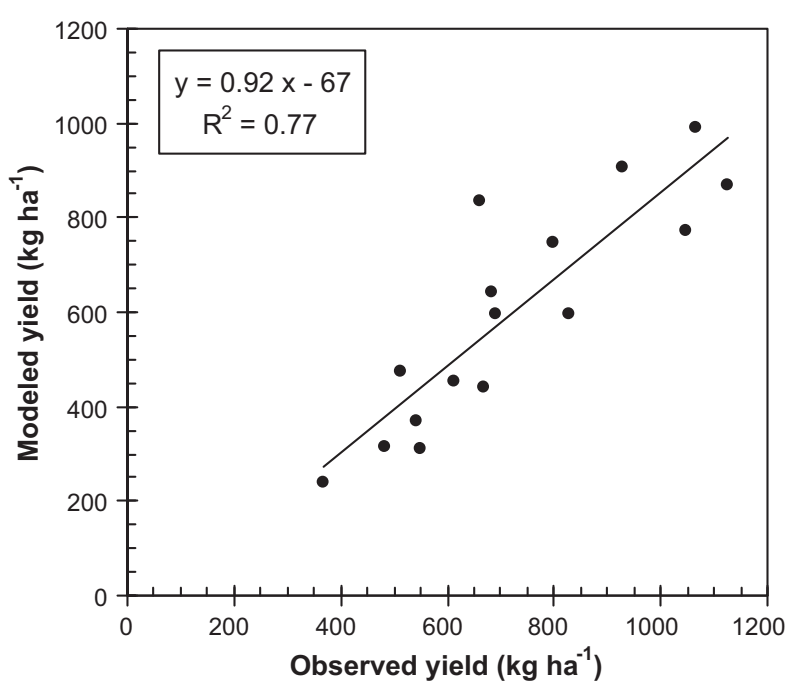

Fig. 5. Comparison between observed and APSIM simulated millet grain yield for an on-station experiment at ICRISAT Sahelian centre. The data cover a range of manure $\left(0-2700 \mathrm{~kg} \mathrm{ha}^{-1}\right)$, crop residue $\left(0-900 \mathrm{~kg} \mathrm{ha}^{-1}\right)$ and fertilizer application rates $\left(0-45 \mathrm{~kg} \mathrm{~N}\right.$ and $\left.0-13 \mathrm{~kg} \mathrm{Pha}^{-1}\right)$ and pertain to two years with contrasting rainfall conditions. Modified from Akponikpè et al. (2010). relatively good but grain yield tended to be slightly underpredicted (Akponikpè et al., 2010). The RMSE represented between 20\% and $30 \%$ of the mean yield, which is the same order of magnitude as commonly reported coefficients of variation of yields within farmer fields in the Sahelian Niger (Brouwer et al., 1993). The model was able to adequately reproduce the average trend of millet grain yield response to $\mathrm{N}$ inputs from manure and fertilizer for low levels of millet stover mulch, and to predict the overall higher grain yield observed in 1995 compared to 1994, despite the better rainfall in 1994.

Depending on the year and field, millet grain yields measured in farmer's fields at Banizoumbou in 2004 and 2005 varied from 80 to $900 \mathrm{~kg} \mathrm{ha}^{-1}$, which is of the same magnitude as simulated grain yields by the APSIM model (typically $0-1000 \mathrm{~kg} \mathrm{ha}^{-1}$ ). Direct comparison of these measurements with simulated results proved unsatisfactory. This can easily be explained by the fact that some sensitive parameters such as initial soil nitrate content, total organic carbon content, inert fraction of organic carbon and $\mathrm{C} / \mathrm{N}$ ratio of soil organic matter (Akponikpè, 2008) were not measured but may have differed substantially across fields. In addition, biotic factors such as pest and disease are not taken into account in APSIM but may also explain in part the observed yield differences.

\subsubsection{Sowing events}

Both ground checking households sowed on 19 May and 30 May in 2004 and 2005, respectively, which agreed with the APSIM simulated sowing dates. Simulations showed that the date of the first
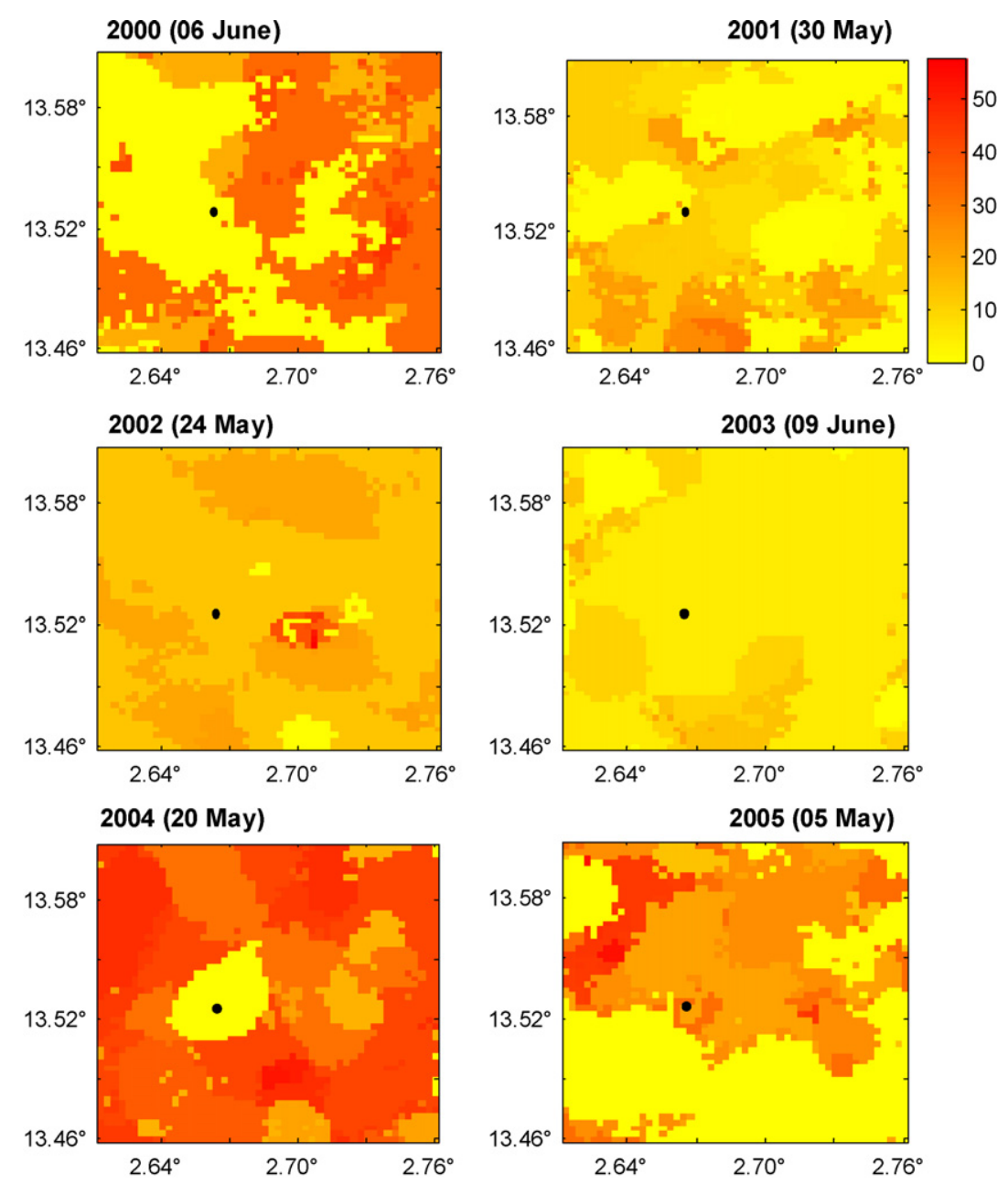

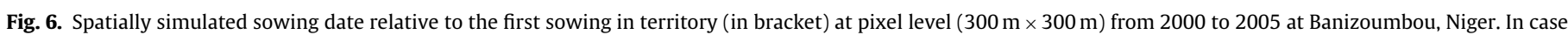
of resowing on a given pixel, the date of the second sowing was considered. The black dot is the centre of the Banizoumbou village. 
2000

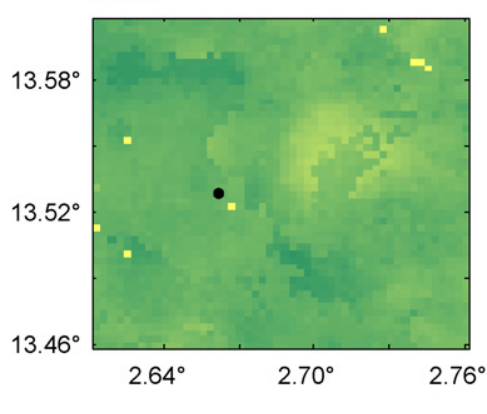

2002

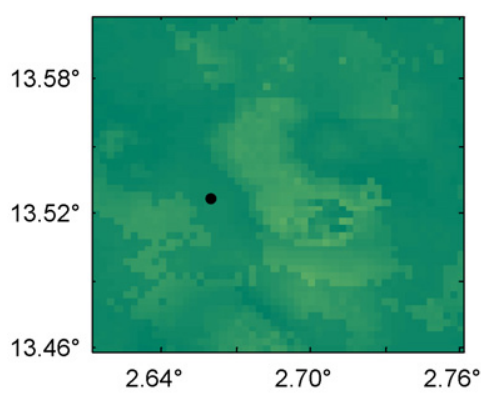

2004

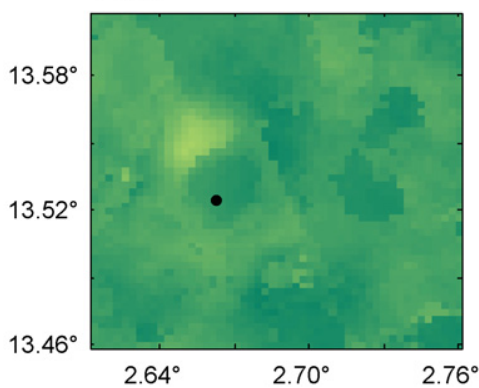

2001

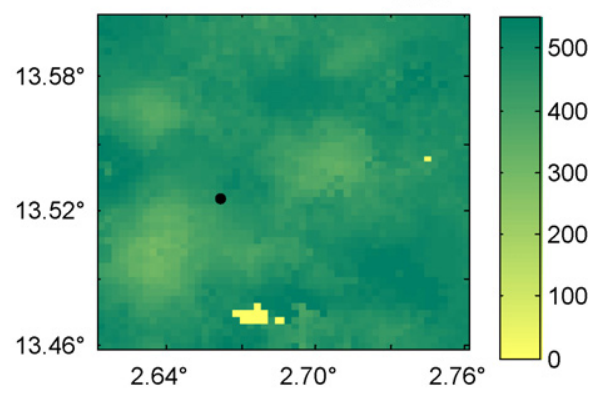

2003

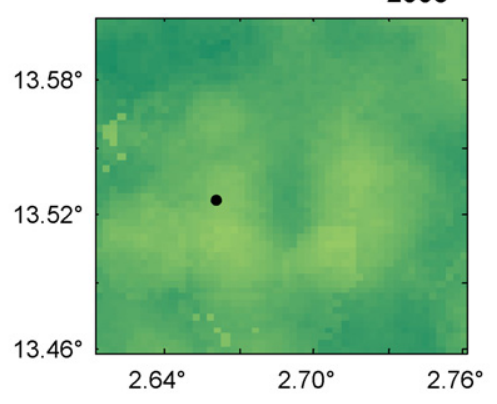

2005

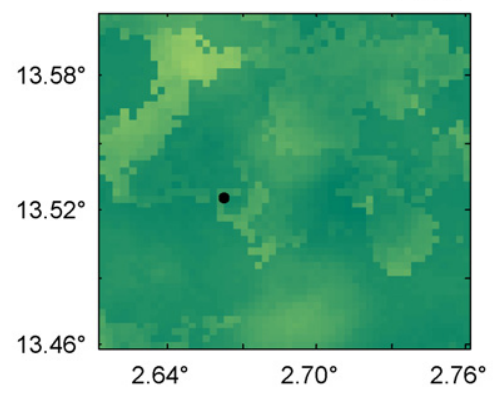

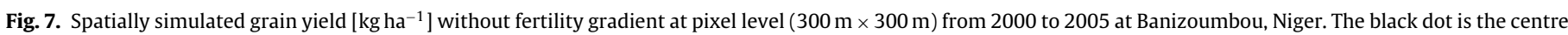
of the Banizoumbou village.

sowing varied spatially very much between pixels (Fig. 6). The earliest sowing took place on May 05 in 2005 and the latest on July 18 in 2000 and 2002 for the Banizoumbou rainfall dataset. The maximum range between the earliest and latest sowing date (at pixel level) varied from 21 (2003) to 55 days (in 2002). A resowing was necessary in 2000 and 2001 in some parts of the village territory (not shown).

\subsubsection{Annual biomass and grain yields}

At the pixel scale, biomass and grain yields were generally spatially coherent, i.e., the yield of a pixel was closely related to those of its neighbours, both without (Fig. 7) or in the presence of a fertility gradient (Fig. 8). Abrupt changes in yield can, however, be observed in two cases: when there is a difference in sowing date between two fields, and at the edge of the fertility zones (Fig. 8). The spatial structure of biomass and grain yields were similar, the average coefficient of correlation between the two variables was indeed greater than 0.9 indicating no important variation in harvest index over the study area. An opposite trend was perceptible when comparing the spatial structure of sowing dates and yields, i.e., late sowing tended to induce lower yields, and the yield pattern was sometimes particularly well explained by the sowing date pattern. The relation between annual rainfall and biomass or grain yields was low to moderate. The correlation coefficient between grain yield and annual rainfall varied between -0.20 and 0.30 depending on the year.

Without fertility gradient, the average, household-level yields varied between 334 and $542 \mathrm{~kg} \mathrm{ha}^{-1}$ for grain yield and between 1609 and $3031 \mathrm{~kg} \mathrm{ha}^{-1}$ for biomass, with slightly higher values in the presence of a fertility gradient around the village (Table 1). The variability of biomass and grain yields across households was almost always higher than the variability of rainfall, with a CV ranging from $4 \%$ to $26 \%$ depending on site and year in the absence of fertility gradient around the village, with a maximum range from 60 to $466 \mathrm{~kg} \mathrm{ha}^{-1}$ for grain yield and 647 to $3200 \mathrm{~kg} \mathrm{ha}^{-1}$ for biomass yield. Taking into account the fertility gradient around the village tended to increase the maximum ranges and CV (Table 1, Fig. 8).

\subsection{Agro-climatic risk indices}

The variability of biomass and grain yields was higher between years within the same household $\left[646 \mathrm{~kg} \mathrm{ha}^{-1}(18 \% \mathrm{CV})\right.$ for INST(BY) and $103 \mathrm{~kg} \mathrm{ha}^{-1}$ (16\%) for INST(GY)] than between a household and the average village-wide yield [359 $\mathrm{kg} \mathrm{ha}^{-1}(36 \%)$ for DISP(BY) and $56 \mathrm{~kg} \mathrm{ha}^{-1}$ (35\%) for DISP(GY)] (Fig. 9). INST(BY) and INST(GY) tended to decrease when taking into account the fertility gradient around the village, whereas those of DISP(BY) and DISP(GY) tended to slightly increase (Fig. 9). 
2000

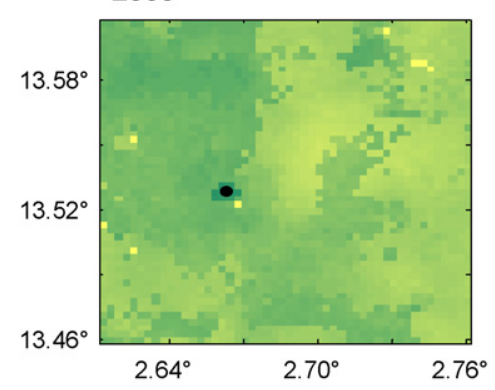

2002

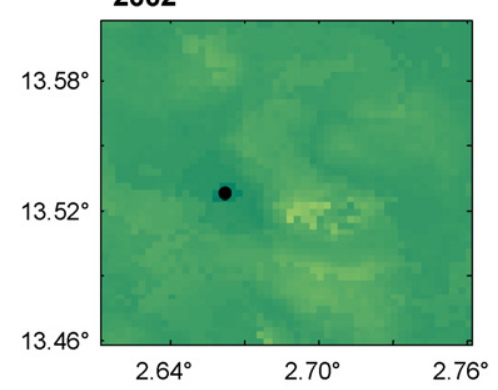

2004

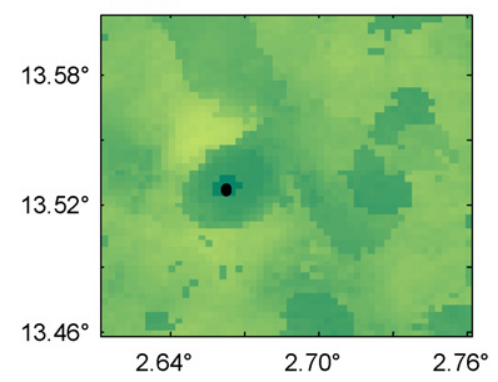

2001

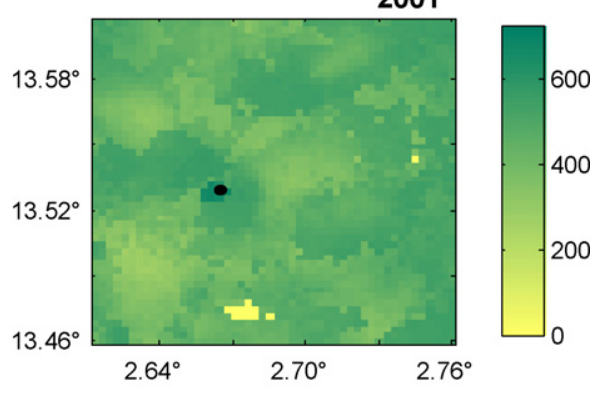

2003

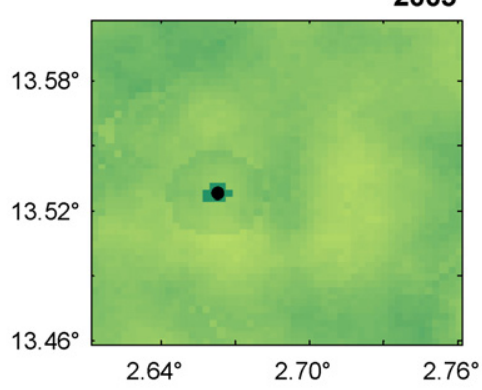

2005

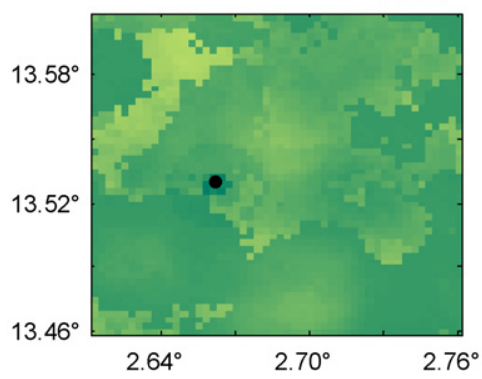

Fig. 8. Spatially simulated grain yield [ $\left.\mathrm{kg} \mathrm{ha}^{-1}\right]$ with fertility gradient at pixel level $(300 \mathrm{~m} \times 300 \mathrm{~m})$ from 2000 to 2005 at Banizoumbou, Niger. The black dot is the centre of the Banizoumbou village.

\subsection{Relation between ISDF and agro-climatic risk indices of household fields}

The values of ISDF ranged between 0.17 and $1.96 \mathrm{~km}$ excluding the households with only a single field (i.e., ISDF $=0$ ). In general, the agro-climatic risk indices decreased linearly with increasing values of the ISDF, as illustrated in Fig. 10a and b. The relations between ISDF and INST(BY) or INST(GY) were statistically significant except for the Kodey rainfall sub-dataset (though all with negative slope; Table 2), revealing that the inter-annual millet yield variability at household-level tended to decrease with increasing field dispersion. The slope of the regression is rather slight, however. The presence of a fertility gradient tended to further reduce the slope (in absolute terms), i.e., increased field dispersion reduced INST(GY) or INST(BY) less strongly when a fertility gradient is taken into account. In fact, by introducing a fertility gradient, yield stability increases (lower SD) only for the households with weakly dispersed fields, as indicated by the lower value of the intercept in the presence of a fertility gradient as compared to the situation without fertility gradient. For high levels of ISDF, the two linear regressions converge (Fig. 10), which indicates no added value of the fertility gradient scenario in terms of reducing inter-annual yield variability compared to the reference situation without fertility gradient.

Similar to the instability index, the linear regressions between ISDF and DISP(BY) or DISP(GY) were all highly significant, with negative slopes for the two fertility scenarios around the village (Table 2). This indicates that the disparity in millet yields among households in a given year tended to decrease with increasing spatial dispersion of fields. Taking into account the fertility gradient tended to increase the slope (in absolute terms), i.e., increased field dispersion reduced DISP(GY) or DISP(BY) more strongly when a fertility gradient is present. This increase in slope mostly results from a larger value of the disparity index for households with low field dispersion, as can be seen from the higher value of the intercept of the regression. For households with strongly dispersed fields, there is little difference in the value of the disparity index with or without fertility gradient.

\section{Discussion}

The main objective of this study was to evaluate the impact of spatial rainfall variability on household millet production and to test the often quoted hypothesis that household field dispersion, as observed in the traditional land tenure, helps mitigate agro-climatic risks in the Sahel. This is made possible through the availability of a high resolution spatial rainfall dataset and a validated crop simulation model.

We found that the range of annual rainfall across the territory was high at pixel level (187-265 mm over $15 \mathrm{~km}$, corresponding to $12-18 \mathrm{~mm} \mathrm{~km}^{-1}$ and a CV of $10 \%$ ) whereas for the aggregated rainfall at household level, it was $100-212 \mathrm{~mm}$ over $15 \mathrm{~km}$ or 7-14 $\mathrm{mm} \mathrm{km}^{-1}$ and a CV of 4-10\% (Table 1 ). There was a smoothing effect of spatial variability when aggregating (average) from pixel to farm field and to household levels. Even higher annual rainfall 

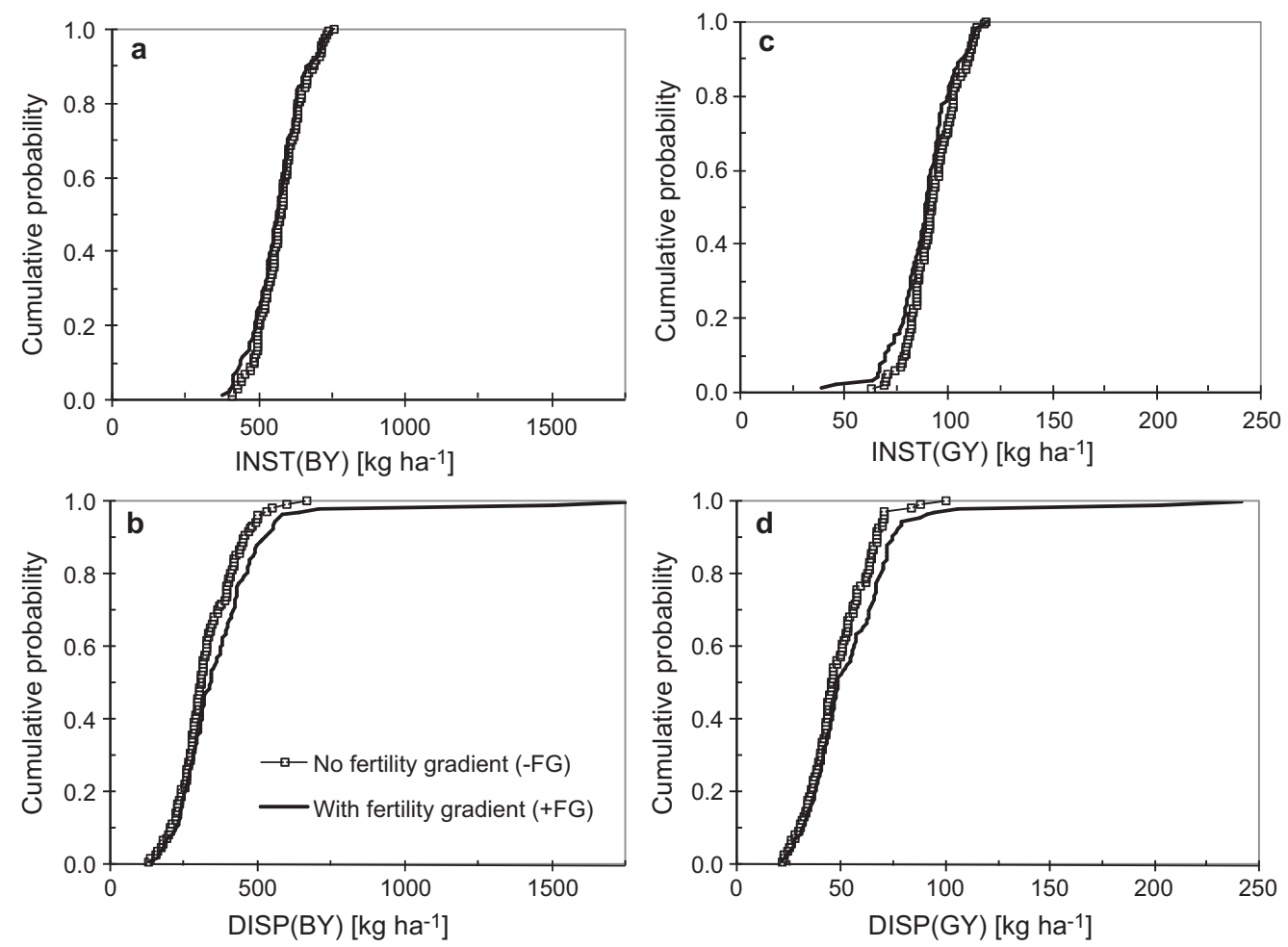

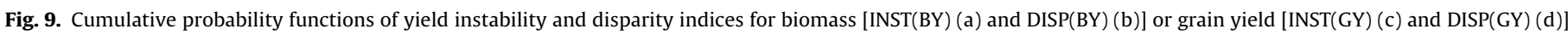
accounting for the fertility gradient (+FG) around the Banizoumbou village or not ( $-\mathrm{FG}$ ).

gradients of $42 \mathrm{~mm} \mathrm{~km}^{-1}$ and $64 \mathrm{~mm} \mathrm{~km}^{-1}$ were reported by Graef (2000) at the ISC (500 ha) in 1995 and 1996, respectively. The spatial variability of cumulative annual rainfall was lower than the one at daily level due to a smoothing effect when aggregating from daily to annual scale.

The range of yields simulated by APSIM is consistent with field observations obtained in the Fakara or from an on-station experiment performed under soil and climatic conditions very similar to those of the study area. As demonstrated by Akponikpè et al. (2010), the APSIM model is able to reproduce satisfactorily millet response to a range of nutrient input levels.

The correlation between the annual rainfall and the yields (biomass or grain) at pixel level was low and depended on the year and pixel location (rainfall condition). This is a well-known fact in the Sahelian environment. From the analysis of 32 years of climatic data and crop yields, Popov (1984) found that yield could not be adequately explained by changes in annual rainfall in the range of 400-1200 mm of annual rainfall. The same low correlation between annual rainfall and yield was also reported by De Rouw and Rajot

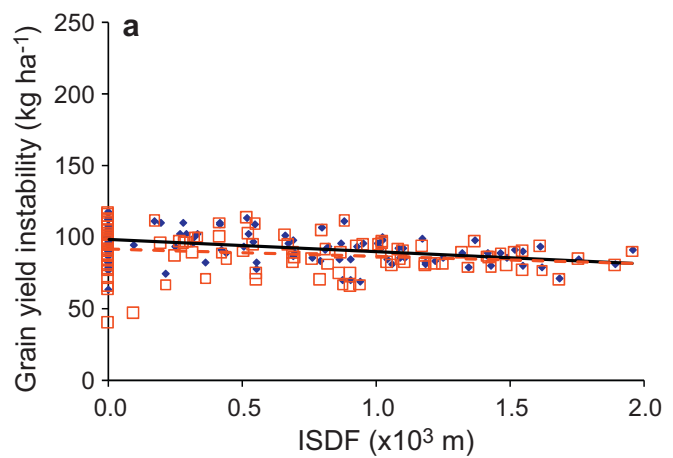

(2004b). Rainfall distribution, sowing conditions and soil fertility management are to be integrated together to adequately predict crop yield in the Sahel. Our model simulations showed that the spatial yield patterns are highly related with the sowing date maps (Fig. 6). Late sowings, which were delayed by as much as 21-55 days within the village territory depending on the year, often induced lower yields due to millet water stress towards the end of the cropping season. Indeed, Sivakumar (1988) showed that the date of ending of the rainy season is much less variable than the date of onset, which makes late sowings more likely to be affected by end of season water and nutrient deficits (Do et al., 1996; Winkel et al., 1997).

At the pixel level simulated grain and biomass yields were comparable to published values in the area with and without various soil amendments (Bationo and Mokwunye, 1991; Bielders and Michels, 2002; De Rouw and Rajot, 2004a,b) and, for a given date of sowing and fertility level, were spatially coherent. The spatial variability of annual rainfall induced an even greater spatial variability of millet production. At the household level, the coefficients of vari-

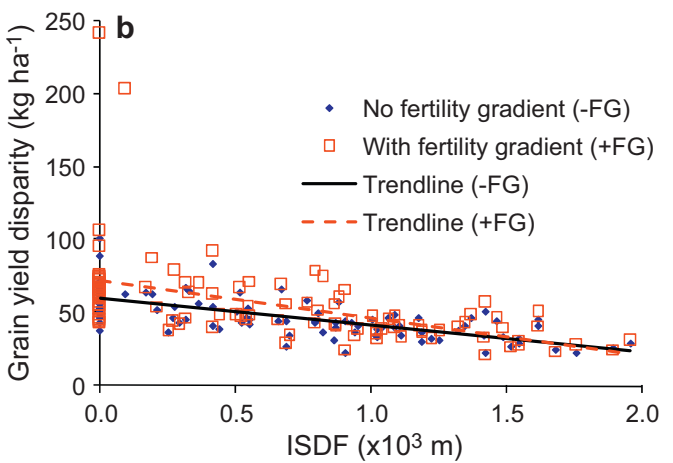

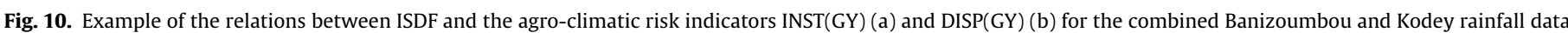
(12 years) and the Banizoumbou land tenure. 
Table 2

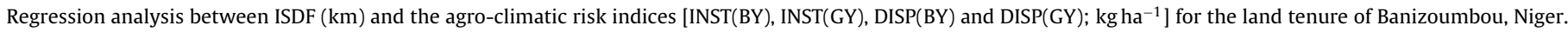
- FG and +FG are scenarios without and with fertility gradient around the village, respectively.

\begin{tabular}{|c|c|c|c|c|c|}
\hline \multirow[t]{2}{*}{ Rainfall data } & & \multicolumn{2}{|l|}{ INST(BY) } & \multicolumn{2}{|l|}{ INST(GY) } \\
\hline & & $-\mathrm{FG}$ & $+\mathrm{FG}$ & $-\mathrm{FG}$ & $+\mathrm{FG}$ \\
\hline Banizoumbou ${ }^{\mathrm{a}}$ (6 years) & $\begin{array}{l}\text { Slope } \\
\text { Intercept } \\
R^{2}\end{array}$ & $\begin{array}{l}-64.5^{* *} \\
686.3^{* * *} \\
0.10^{* *}\end{array}$ & $\begin{array}{l}-52.7^{*} \\
657.9^{* * *} \\
0.06^{*}\end{array}$ & $\begin{array}{l}-12.0^{* * *} \\
110.8^{* * *} \\
0.16^{* * *}\end{array}$ & $\begin{array}{l}-8.4^{* *} \\
103.2^{* * *} \\
0.07^{* *}\end{array}$ \\
\hline Banizoumbour ${ }^{\mathrm{b}}$ (6 years) & $\begin{array}{l}\text { Slope } \\
\text { Intercept } \\
R^{2}\end{array}$ & $\begin{array}{l}-24.4^{\mathrm{ns}} \\
508.5^{* * *} \\
0.01^{\mathrm{ns}}\end{array}$ & $\begin{array}{l}-17.5^{\mathrm{ns}} \\
492.7^{* * *} \\
0.00^{\mathrm{ns}}\end{array}$ & $\begin{array}{l}-2.3^{\text {ns }} \\
81.5^{* * *} \\
0.00^{\text {ns }}\end{array}$ & $\begin{array}{l}-0.7^{\mathrm{ns}} \\
77.6^{* * *} \\
0.00^{\mathrm{ns}}\end{array}$ \\
\hline \multirow[t]{3}{*}{ Banizoumbou (12 years) } & $\begin{array}{l}\text { Slope } \\
\text { Intercept } \\
R^{2}\end{array}$ & $\begin{array}{l}-50.4^{* * *} \\
610.8^{* * *} \\
0.14^{* * *}\end{array}$ & $\begin{array}{l}-42.9^{* * *} \\
591.9^{* * *} \\
0.08^{* * *}\end{array}$ & $\begin{array}{l}-8.1^{* * *} \\
97.5^{* * *} \\
0.16^{* * *}\end{array}$ & $\begin{array}{l}-5.4^{*} \\
91.7^{* * *} \\
0.05^{*}\end{array}$ \\
\hline & & \multicolumn{2}{|l|}{$\operatorname{DISP}(\mathrm{BY})$} & \multicolumn{2}{|l|}{$\operatorname{DISP}(G Y)$} \\
\hline & & $-\mathrm{FG}$ & $+\mathrm{FG}$ & $-\mathrm{FG}$ & $+\mathrm{FG}$ \\
\hline Banizoumbou $^{\mathrm{a}}$ (6 years) & $\begin{array}{l}\text { Slope } \\
\text { Intercept } \\
R^{2}\end{array}$ & $\begin{array}{l}-145.2^{* * *} \\
450.1^{* * *} \\
0.41^{* * *}\end{array}$ & $\begin{array}{l}-194.6^{* * * *} \\
530.4^{* * *} \\
0.24^{* * *}\end{array}$ & $\begin{array}{l}-23.3^{* * *} \\
70.8^{* * *} \\
0.46^{* * *}\end{array}$ & $\begin{array}{l}-30.8^{* * *} \\
82.7^{* * *} \\
0.28^{* * *}\end{array}$ \\
\hline Banizoumbou $^{\mathrm{b}}$ (6 years) & $\begin{array}{l}\text { Slope } \\
\text { Intercept } \\
R^{2}\end{array}$ & $\begin{array}{l}-111.4^{* * *} \\
378.9^{* * *} \\
0.30^{* * *}\end{array}$ & $\begin{array}{l}-164.1^{* * *} \\
469.5^{* * *} \\
0.15^{* * *}\end{array}$ & $\begin{array}{l}-14.5^{* * *} \\
52.5^{* * *} \\
0.26^{* * *}\end{array}$ & $\begin{array}{l}-21.3^{* * *} \\
64.2^{* * *} \\
0.16^{* * *}\end{array}$ \\
\hline Banizoumbou (12 years) & $\begin{array}{l}\text { Slope } \\
\text { Intercept } \\
R^{2}\end{array}$ & $\begin{array}{l}-125.0^{* * *} \\
403.3^{* * *} \\
0.50^{* * *}\end{array}$ & $\begin{array}{l}-173.1^{* * *} \\
485.0^{* * *} \\
0.22^{* * *}\end{array}$ & $\begin{array}{l}-18.6^{* * *} \\
60.3^{* * *} \\
0.51^{* * *}\end{array}$ & $\begin{array}{l}-25.3^{* * *} \\
71.5^{* * *} \\
0.25^{* * *}\end{array}$ \\
\hline
\end{tabular}

ns, not significant.

a Land tenure and rainfall data for the Banizoumbou territory.

b Land tenure data from Banizoumbou but rainfall data from another but closeby territory (Kodey).

* Probability significant at 0.05 .

** Probability significant at 0.01 .

*** Probability significant at 0.001 .

ation of biomass and grain yields (4-26\%) were high and higher than the CV of annual rainfall (4-10\%). This could be ascribed to the fact that yield is more dependent on daily rainfall distribution than on the cumulative annual amount, i.e., moving from daily to annual scale smoothes in a significant way the rainfall variability. Taking into account the fertility gradient around the village tended to increase, in a significant way, the upper limit of the ranges and CV of millet production. Hence, adding a fertility gradient introduced an additional source of yield variability.

The relations between ISDF and the yield instability indices INST(BY) and INST(GY) were all significant when considering the 12-year rainfall dataset (Table 2), with negative slopes. This is evidence that field dispersion does indeed reduce inter-annual yield variability at household level and hence reduces the risk of severe household food deficits. However, the slope of the regressions is fairly weak. For instance, the grain yield instability index (INST(GY)) decreases from $97.5 \mathrm{~kg} \mathrm{ha}^{-1}$ for households with single fields $(I S D F=0)$ to $81.3 \mathrm{~kg} \mathrm{ha}^{-1}$ when the ISDF reaches $2 \mathrm{~km}(12-$ year data, Table 2). In order to better apprehend the impact of this $17 \%$ reduction in the instability index, let us consider the average household-level yield of $435 \mathrm{~kg} g r a i n ~ h a^{-1}$ irrespective of the degree of field dispersion (12-year average of the no fertility gradient scenario; Table 1) and that household-level inter-annual grain yield is normally distributed. Let us further assume that a yield of $300 \mathrm{~kg} \mathrm{ha}^{-1}$ would result in food shortage at the household level. Consequently, there would be an $8 \%$ probability ( 1 in 12 years) for grain yields to drop below $300 \mathrm{~kg} \mathrm{ha}^{-1}$ for single-field households. This probability drops to $5 \%$ ( 1 in 20 years) for households with highly dispersed fields. Hence, one may conclude that field dispersion indeed contributes moderately but significantly to a reduction in the occurrence of household-level food shortage.

Introducing a fertility gradient reduces the instability index by $12 \%$, from $91.7 \mathrm{~kg} \mathrm{ha}^{-1}$ for single-field households to $80.9 \mathrm{~kg} \mathrm{ha}^{-1}$ when the ISDF reaches $2 \mathrm{~km}$. Clearly, the more dispersed the fields of a household, the lower the contribution of the fertility gradient to a reduction of the instability index.

The disparity index reflects to what extent households differ from each other in terms of average yield. It may be considered that a low disparity among households is a desirable situation in the context of a traditional society resting on subsistence farming. Indeed, as poor yields are frequently interpreted as not just the result of a random climatic factor but also as a punishment for some disrespectful actions, it may be desirable for a household not to have much worse yields than the average village scale yield. The disadvantage associated with lower yields than average may offset any benefits to be drawn from having higher yields than average.

The significant linear regressions between ISDF and DISP(BY) or DISP(GY) confirm that the more dispersed farm fields are in a given household, the less its yield is different from the yields of the other households in the village territory for a given year. Disparity among households therefore decreases as household fields are more scattered. Introducing a fertility gradient enhances this effect (steeper slope of the regression). Actually, introducing a fertility gradient does have little impact on the disparity index for households with strongly scattered fields, but it enhances rather than decreases disparity among households with little dispersed fields. Indeed, for single-field households, the disparity index decreases from 71.5 to $60.3 \mathrm{~kg} \mathrm{ha}^{-1}$ with and without fertility gradient, respectively. The increase in disparity in the presence of a fertility gradient may result from the fact that only few households have fields in the higher fertility zones. These households would tend to have higher yields on average, thereby increasing the upper range of predicted household-level yields and hence the disparity. This effect is much smaller for large values of ISDF. Indeed, for an ISDF of $2 \mathrm{~km}$, the disparity index reaches 20.9 and $23.1 \mathrm{~kg} \mathrm{ha}^{-1}$ with and without fertility gradient, respectively. This may be explained by the fact 
that the high yield of the high fertility fields is diluted by the more distant, lower fertility fields of the household. When a household has several fields, including a high fertility one, its mean yield is less different from the average yield of all households than if the household had only one, high fertility field.

Household field dispersion results both from historical reasons (i.e., land inheritance), decisions made by the village chief when newcomers or villagers ask for more land, and arrangements among farmers (different types of leasing). The latter provides farmers with the most leverage to ensure proper field dispersion, although presumably village chiefs may also avoid attributing large tracts of land in one block to a single household. Because agriculture is not mechanized in the Fakara, i.e., sowing, weeding, manuring and harvesting are done by hand, field dispersion is not a costly strategy. Indeed, except for sowing which involves the entire household and can be done very fast (in theory, several fields in one day), other tasks require several days per field to be completed. Hence, walking or carrying manure to several smaller fields rather than one single field, all fields being located at the same distance from the village, does not imply additional waste of time. Obviously, it is preferable to have a closeby field rather than a faraway field, but as the land acreage close to the village is by definition very limited, most farmers will need to combine closeby fields with more distant fields to satisfy their production requirements. At the current stage of agricultural development, field dispersion therefore implies few, if any, disadvantages.

\section{Conclusions}

We combined GIS information, spatially distributed rainfall data, fertility management information and a process-based plantgrowth model to evaluate a traditional strategy of nigerien farmers for agro-climatic risk management. This analysis was made possible thanks to the availability of a dense rain gauge network monitored continuously over several years. The main outcomes of this work are the following: (1) the spatial variability of annual rainfall induces an even higher spatial variability of millet production, both at pixel and household levels; (2) the fertility gradient around the village increases the millet yield variability between households in a given territory; (3) the more dispersed the farm fields of a given household are, the less its yield is different from the village-level average millet yield in a given year; (4) field dispersion moderately but significantly increases the inter-annual yield stability in a household, thereby reducing the probability of occurrence of severe food shortages; (5) the presence of a fertility gradient has a similar effect, but only for households with weakly scattered fields. Our findings should be confirmed by further research using longer term spatial rainfall data. Furthermore, the analysis may be refined by improving the spatial rainfall analysis. In the mean time, it is advisable that any land reforms in the area take account of this traditional climate risk mitigation strategy.

\section{Acknowledgement}

This research was part of the project entitled 'Improved livelihoods in the Sahel through the development and implementation of household level bio-economic decision support systems' funded by the Belgian Development Cooperation (DGDC). We thank Luc Descroix of the Institut de Recherche pour le Développement (IRD, Niger) for providing the high resolution rainfall data of Banizoumbou and Eduardo C. de Araujo Marinho F. for his rewarding discussions and for drawing our attention to the use of the ISDF index. The valuable contribution by the anonymous referees in the review process is gratefully acknowledged.

\section{References}

Akponikpè, P.B.I., 2008. Millet response to water and soil fertility management in the Sahelian Niger: experiments and modelling. Ph.D. dissertation, Université catholique de Louvain, Louvain-la-Neuve, Belgium, $168 \mathrm{pp}$.

Akponikpè, P.B.I., Bielders, C.L., Gérard, B., Michels, K., 2006. Simulation of millet response to combined application of cattle manure, millet residue and chemical fertilizer in the Sahel using APSIM. In: Agricultural Research Western Australia (Ed.), Ground-breaking Stuff. Proceedings of the 13th Australian Society of Agronomy Conference. ASA, Perth, Australia.

Akponikpè, P.B.I., Gérard, B., Michels, K., Bielders, C.L., 2010. Use of the APSIM model in long term simulation to support decision making regarding nitrogen management for pearl millet in the Sahel. Eur. J. Agron. 32, 144-154.

Baidu-Forson, J., 1995. Determinants of the availability of adequate millet stover for mulching in the Sahel. J. Sustain. Agric. 5, 101-116.

Bationo, A., Mokwunye, A.U., 1991. Alleviating soil fertility constraints to increased crop production in West Africa-the experience in the Sahel. Fert. Res. 29, 95-115.

Bielders, C.L., Michels, K., 2002. On-farm evaluation of ridging and residue management options in a Sahelian millet-cowpea intercrop. 2. Crop development. Soil Use Manage. 18, 309-315.

Bishop, M.A., 2007. Point pattern analysis of eruption points for the Mount Gambier volcanic sub-province: a quantitative geographical approach to the understanding of volcano distribution. Area 39 (2), 230-241.

Brouwer, J., Fussell, L.K., Herrmann, L., 1993. Soil and crop growth microvariability in the West-African semiarid tropics-a possible risk-reducing factor for subsistence farmers. Agric. Ecosyst. Environ. 45, 229-238.

Christakos, G., Bogaert, P., Serre, M.L., 2002. Temporal GIS. Advanced Functions for Field-based Applications. Springer-Verlag, New York, NY.

De Rouw, A., Rajot, J.L., 2004a. Nutrient availability and pearl millet production in Sahelian farming systems based on manuring or fallowing. Agric. Ecosyst. Environ. 104, 249-262.

De Rouw, A., Rajot, J.L., 2004b. Soil organic matter, surface crusting and erosion in Sahelian farming systems based on manuring or fallowing. Agric. Ecosyst. Environ. 104, 263-276.

Do, F., Winkel, T., Cournac, L., Louguet, P., 1996. Impact of late-season drought on water relations in a sparse canopy of millet (Pennisetum glaucum (L) R Br). Field Crop. Res. 48, 103-113.

Fechter, J., 1993. The simulation of pearl millet (Pennisetum glaucum L.) growth under the environmental conditions of southwestern Niger, West Africa. Universität Hohenheim, Institute für Bodenkunde und Standorslehre, Hohenheim, Germany.

Flitcroft, I.D., Milford, J.R., Dugdale, G., 1989. Relating point to area average rainfal in semiarid West-Africa and the implications for rainfall estimates derived from satellite data. J. Appl. Meteorol. 28, 252-266.

Gérard, B., Buerkert, A., 1999. Aerial photography to determine fertiliser effects on pearl millet and Guiera senegalensis growth. Plant Soil 210, 167177.

Graef, F., 2000. Agroclimatology in southwestern Niger-implication for crop growth and crop management. In: Graef, F., Lawrence, P., von Oppen, M.E.(Eds.), Adapted Farming in West Africa: Issues, Potentials and Perspectives. Verlag Ulrich E. Grauer, Stuttgart, Germany, pp. 27-31.

Graef, F., Haigis, J., 2001. Spatial and temporal rainfall variability in the Sahel and its effects on farmers' management strategies. J. Arid Environ. 48, 221-231.

Hiernaux, P., Ayantunde, A., 2004. The Fakara: a semi-arid agro-ecosystem under stress. Report of research activities, Niamey, Niger, ILRI/DMP.

Hoogmoed, W.B., Stroosnijder, L., 1984. Crust formation on sandy soils in the Sahel. 1. Rainfall and infiltration. Soil Till. Res. 4, 5-23.

Hunt, B.G., 2000. Natural climatic variability and Sahelian rainfall trends. Globa Planet. Change 24, 107-131.

Keating, B.A., Carberry, P.S., Hammer, G.L., Probert, M.E., Robertson, M.J., Holzworth, D., Huth, N.I., Hargreaves, J.N.G., Meinke, H., Hochman, Z., Mclean, G., Verburg, K., Snow, V., Dimes, J.P., Silburn, M., Wang, E., Brown, S., Bristow, K.L., Asseng, S., Chapman, S., Mccown, R.L., Freebairn, D.M., Smith, C.J., 2003. An overview of APSIM, a model designed for farming systems simulation. Eur. J. Agron. 18, 267-288.

La Rovere, R., Hiernaux, P., Van Keulen, H., Schiere, J.B., Szonyi, J.A., 2004 Co-evolutionary scenarios of intensification and privatization of resource use in rural communities of south-western Niger. Agric. Syst. 83, 251 276.

Le Barbe, L., Lebel, T., 1997. Rainfall climatology of the HAPEX-Sahel region during the years 1950-1990. J. Hydrol. 188-189, 43-73.

Marinho, E., 2008. Economics of hunger: several methods, levels and scales. Ph.D. dissertation, Université catholique de Louvain, Louvain-la-Neuve, Belgium, 155 pp.

Payne, W.A., 2000. Optimizing crop water use in sparse stands of pearl millet. Agron. J. 92, 808-814.

Popov, G.F., 1984. Crop monitoring and forecasting. Agrometeorology of sorghum and millet in the semi-arid tropics. In: Proceedings of an International Workshop. ICRISAT, Patancheru, AP, India.

Sivakumar, M.V.K., 1988. Predicting rainy season potential from the onset of rains in Southern Sahelian and Sudanian climatic zones of West Africa. Agric. Forest Meteorol. 42, 295-305.

Sivakumar, M.V.K., 1989. Agroclimatic aspects of rainfed agriculture in the SudanoSahelian zone. In: Sivakumar, M.V.K., Wallace, J.S., Renard, C., Giroux, C. (Eds.), Soil, Crop, and Water Management Systems for Rainfed Agriculture in the 
Sudano-Sahelian Zone. Proceedings of an International Workshop. ICRISAT, Patancheru, AP, India.

Sivakumar, M.V.K., 1990. Exploiting rainy season potential from the onset of rains in the Sahelian zone of West-Africa. Agric. Forest Meteorol. 51, 321-332.

Sivakumar, M.V.K., 1992. Empirical-analysis of dry spells for agricultural applications in West Africa. J. Climate 5, 532-539.

Thornton, P.K., Bowen, W.T., Ravelo, A.C., Wilkens, P.W., Farmer, G., Brock, J., Brink, J.E., 1997. Estimating millet production for famine early warning: an application of crop simulation modelling using satellite and ground-based data in Burkina Faso. Agric. Forest Meteorol. 83, 95-112.
Valentin, C., 1991. Surface crusting in two alluvial soils of northern Niger. Geoderma 48, 201-222.

Valentin, C., D'herbes, J.M., 1999. Niger tiger bush as a natural water harvesting system. Catena 37, 231-256.

Voortman, R.L., Brouwer, J., Albersen, P.J., 2004. Characterization of spatial soil variability and its effect on millet yield on Sudano-Sahelian coversands in SouthWest Niger. Geoderma 121, 65-82.

Winkel, T., Renno, J., Payne, W., 1997. Effect of the timing of water deficit on growth, phenology and yield of pearl millet (Pennisetum glaucum (L.) R. Br.) grown in Sahelian conditions. J. Exp. Bot. 48 (310), 1001-1009. 